\title{
APLIKASI DATA PASIEN DAN PENENTUAN GIZI IBU HAMIL PADA PUSKESMAS SUNGAI TABUK
}

\author{
Mayang Sari, S.Kom, M.Kom \\ Teknik Informatika, Fakultas Teknik Informatika (mayangsari.si@gmail.com)
}

\begin{abstract}
ABSTRAK
Penelitian ini dilakukan dengan maksud untuk Mempermudah dan mempercepat analisa sehingga puskesmas dapat dengan cepat menentukan langkah dan kebijakan dengan berdasarkan hasil pelaporan dan terorganisirnya setiap kegiatan baik dari data pasien, data KIR, data rujukan dan perhitungan gizi ibu hamil yang dilakukan oleh puskesmas tersebut. Puskesmas Rawat Inap Sungai Tabuk merupakan puskesmas pembantu yang terletak di Kecamatan Sungai Tabuk, kabupaten Banjar Kalimantan Selatan. Puskesmas ini memberikan pelayanan kesehatan bagi masyarakat di sekitar wilayah Sungai Tabuk maupun di sekitarnya. Puskesmas ini didirikan untuk membantu masyarakat di daerah Sungai Tabuk dan sekitarnya - Puskesmas tersebut memberikan pelayanan kesehatan bagi masyarakat dengan sistem pengobatan rawat jalan. Untuk menciptakan pendataan pasien, diperlukan pengelolaan yang baik pula dari bagian yang menangani hal tersebut. Di luar masalah teknis operasional, pengelolaan data pasien yang baik disuatu instansi kesehatan umum dapat ditentukan dari mekanisme administrasinya. Mekanisme administrasi yang baik dan menciptakan kemudahan dan efisiensi dalam proses pencatatan maupun pengambilan informasi. Dengan kemudahan dan efisiensi tersebut, diharapkan informasi yang ada dapat diguakan secara optimal, diolah sedemikian rupa, sehingga akan sangat membantu dalam menentukan tindakan-tindakan medis yang harus dilakukan.
\end{abstract}

Kata Kunci : Puskesmas, Gizi, Kehamilan, Sungai Tabuk

\section{ABSTRACT}

This research was conducted with the intention to simplify and speed up the analysis so that the puskesmas can quickly determine steps and policies based on the results of reporting and the organization of each activity both from patient data, KIR data, reference data and nutrition calculation for pregnant women carried out by the puskesmas. Sungai Tabuk Inpatient Health Center is an auxiliary health center located in Sungai Tabuk Subdistrict, Banjar Regency, South Kalimantan. This health center provides health services for the community around Sungai Tabuk region and surrounding areas. This puskesmas was established to help the community in the Sungai Tabuk and surrounding areas. The puskesmas provides health services for the community with an outpatient treatment system. To create patient data collection, good management is also needed from the part that handles it. Apart from operational technical issues, good management of patient data in a public health agency can be determined from the administrative mechanism. Good administrative mechanisms and create ease and efficiency in the process of recording and retrieving information. With this ease and efficiency, it is expected that the available information can be used optimally, processed in such a way that it will be very helpful in determining medical actions that must be carried out.

Keywords: Puskesmas, Nutrition, Pregnancy, Sungai Tabuk

Jurnal Ilmiah "Technologia" 


\section{PENDAHULUAN}

Puskesmas Rawat Inap Sungai Tabuk merupakan puskesmas pembantu yang terletak di Kecamatan Sungai Tabuk, kabupaten Banjar Kalimantan Selatan. Puskesmas ini memberikan pelayanan kesehatan bagi masyarakat di sekitar wilayah Sungai Tabuk maupun di sekitarnya. Puskesmas ini didirikan untuk membantu masyarakat di daerah Sungai Tabuk dan sekitarnya . Puskesmas tersebut memberikan pelayanan kesehatan bagi masyarakat dengan sistem pengobatan rawat jalan.

Dalam prakteknya di Puskesmas Sungai Tabuk ini sistem administrasi masih menggunakan cara manual yaitu dalam hal pedaftataran data pasien masih menggunakan kartu dalam bentuk kertas sehingga memperlambat pelayanan, untuk itu alangkah baiknya jika pengolahan data saat masyarakat berobat dibuat Sistem Informasi yang lebih baik.

Sehubungan dengan adanya pasien yang berobat, meminta surat kesehatan dan meminta surat sakit yang harus ditangani serta diperlukan informasi secara tepat dan cepat, maka tidak efisien lagi bila penanganannya hanya dikerjakan dengan cara manual dan belum lagi pasien yang datang setiap harinya mencapai puluhan karena puskesmas ini mencakup banyak desa yang ada di Kecamatan Sungai Tabuk.

Untuk menciptakan pendataan pasien, diperlukan pengelolaan yang baik pula dari bagian yang menangani hal tersebut. Di luar masalah teknis operasional, pengelolaan data pasien yang baik disuatu instansi kesehatan umum dapat ditentukan dari mekanisme administrasinya. Mekanisme administrasi yang baik dan menciptakan kemudahan dan efisiensi dalam proses pencatatan maupun pengambilan informasi. Dengan kemudahan dan efisiensi tersebut, diharapkan informasi yang ada dapat diguakan secara optimal, diolah sedemikian rupa, sehingga akan sangat membantu dalam menentukan tindakantindakan medis yang harus dilakukan.

\section{TINJAUAN PUSTAKA}

\subsection{Pasien}

Menurut Pasal 1 (ayat 10) UndangUndang Nomor 29 Tahun 2004 tentang praktik kedokteran menyebutkan pasien adalah setiap orang yang melakukan konsultasi masalah kesehatannya untuk memperoleh pelayanan kesehatan yang diperlukan baik secara langsung maupun tidak langsung kepada dokter atau dokter gigi.

\subsection{Puskesmas}

Pusat Kesehatan Masyarakat (Puskesmas) adalah salah satu sarana pelayanan kesehatan masyarakat yang amat penting di Indonesia. Puskesmas adalah unit pelaksana teknis dinas kabupaten/kota yang bertanggungjawab menyelenggarakan pembangunan kesehatan di suatau wilayah kerja (Depkes, 2011).

Pengertian puskesmas adalah suatu unit pelaksana fungsional yang berfungsi sebagai pusat pembangunan kesehatan, pusat pembinaan peran serta masyarakat dalam bidang kesehatan serta pusat pelayanan kesehatan tingkat pertama yang menyelenggarakan kegiatannya secara menyeluruh, terpadu yang berkesinambungan pada suatu masyarakat yang bertempat tinggal dalarn suatu wilayah tertentu (Azrul Azwar, 1996).

Puskesmas merupakan kesatuan organisasi fungsional yang menyelenggarakan upaya kesehatan yang bersifat menyeluruh, terpadu, merata dapat diterima dan terjangkau oleh masyarakat dengan peran serta aktif masyarakat dan menggunakan hasil pengembangan ilmu pengetahuan dan teknologi tepat guna, dengan biaya yang dapat dipikul oleh pemerintah dan masyarakat luas guna mencapai derajat kesehatan yang optimal, tanpa mengabaikan mutu pelayanan kepada perorangan (Depkes, 2009). 


\subsection{Gizi}

Pengertian Gizi Secara Umum ialah zat yang dibutuhkan oleh tubuh dalam pertumbuhan, perkembangan, pemeliharaan dan juga memperbaiki jaringan tubuh. Pengertian Gizi ialah dimana gizi berasal dari bahasa mesir yang berarti "Makanan".

Gizi merupakan terjemahan dari kata Nutrition yang disebut sebagai nutrisi. Gizi pun bisa diartikan sebagai sesuatu yang memengaruhi adanya proses perubahan yang ada pada setiap makanan yang masuk dalam tubuh yang bisa mempertahankan tubuh agar tetap sehat. Para ahli yang mempelajari tentang Gizi dikenal sebagai Ilmu Gizi. Pengertian Ilmu Gizi ialah ilmu yang zat-zat gizi yang ada pada makanan dan juga penggunanya dalam tubuh yang meliputi masukan, pencernaan, pengangkutan (transpor), penyerapan, metabolisme, interaksi, dan juga penyimpanan serta pengeluaran, semua hal tersebut ialah proses zat gizi pada tubuh.

\subsection{Ibu Hamil}

Pengertian kehamilan menurut Badan Kependudukan dan Keluarga Berencana Nasional (BKKBN) adalah sebuah proses yang diawali dengan keluarnya sel telur yang matang pada saluran telur yang kemudian bertemu dengan sperma yang keduanya menyatu membentuk sel yang akan tumbuh.

Berdasarkan pengertian ibu hamil dari BKKBN tersebut, dapat diartikan sebagai proses terjadinya kehamilan saat seorang wanita yang membawa embrio di dalam tubuhnya. Secara medis, ibu hamil disebut gravida, sedangkan calon bayi yang dikandungnya saat awal kehamilan disebut embrio dan selanjutnya disebut janin sampai waktu kehamilan tiba.

\subsection{XAMPP}

XAMPP merupakan singkatan $\mathrm{X}$ (empat system operasi apapun), Apache, MySQL, PHP, Perl. XAMPP merupakan tool yang menyediakan paket perangkat lunak ke dalam satu buah paket. Dalam paketnya sudah terdapat Apache (web server), MySQL (database), PHP (server side scripting), Perl, FTP server, phpMyAdmin dan berbagai pustaka bantu lainnya. XAMPP akan menginstalasi dan mengkonfigurasikannya secara otomatis untuk anda. Versi XAMPP yang ada saat ini adalah Versi 1.7.3 yang terdiri atas :

1. Apache 2.2.14 (Ipv6 enabled) + OpenSS1 0.9.8I

2. MySQL 5.1.41 + PBXT engine

3. PHP 5.3.1

4. phpMyAdmin 3.2.4

5. Perl 5.10.1

6. FileZilla FTP Server 0.9.33

7. Mercury Mail Transport System 4.72

\subsection{MySQL}

MySQL adalah sebuah implementasi dari sistem manajemen basisdata relasional RDBMS yang didistribusikan secara gratis dibawah lisensi GPL (General Public License). Setiap pengguna dapat secara bebas menggunakan MySQL, namun dengan batasan perangkat lunak tersebut tidak boleh dijadikan produk turunan yang bersifat komersial. MySQL sebenarnya merupakan turunan salah satu konsep utama dalam basisdata yang telah ada sebelumnya; SQL (Structured Query Language). SQL adalah sebuah konsep pengoperasian basisdata, terutama untuk pemilihan atau seleksi dan pemasukan data, yang memungkinkan pengoperasian data dikerjakan dengan mudah secara otomatis.

\section{METODE PENELITIAN}

Secara umum dalam rangka pengumpulan data yang dilakukan dalam penelitian ini antara lain :

1. Observasi (Observasi Research)

Observasi yang dilakukan dalam penelitian ini merupakan metode pengamatan dan pencatatan secara 
sistematis terhadap objek yang diselidiki. Jadi dalam penelitian ini diselidiki secara langsung yang menyangkut sistem kerja/operasional.

2. Wawancara (Interview Research)

Wawancara merupakan cara pengumpulan data yang dilakukan dengan cara tanya jawab. Dalam wawancara ini dilakukannya pada puskesmas Sungai Tabuk dalam menangani permasalahan yang ada.

3. Studi Pustaka (Study Literature)

Studi pustaka merupakan cara pengumpulan data dengan cara penulis mempelajari referensi-referensi buku, artikel, dan situs internet yang ada hubungannya dengan permasalahan yang penulis jadikan objek dalam penelitian tersebut.

4. Sampling

Sampling merupakan cara pengumpulan data yaitu dengan meneliti dan memilih suatu dokumen yang tersedia. Disini penulis melakukan penelitian dengan cara membentuk golongan dari suatu kumpulan berkas dan data-data yang berisikan tentang tujuan dari pemanfaatan pengumpulan data ke puskesmas tersebut yang masih menggunakan kertas dengan tumpukan data-data yang ada.

\section{HASIL DAN PEMBAHASAN}

\subsection{Diagram Konteks}

Diagram konteks adalah diagram yang terdiri dari suatu proses dan menggambarkan ruang lingkup suatu system. Diagram konteks merupakan level tertinggi dari DFD yang menggambarkan seluruh input ke sistem atau output dari sistem. Ia akan memberi gambaran tentang keseluruhan sistem. Dalam diagram konteks hanya ada satu proses. Berikut adalah gambaran bagaimana sistem aplikasi ini berjalan.

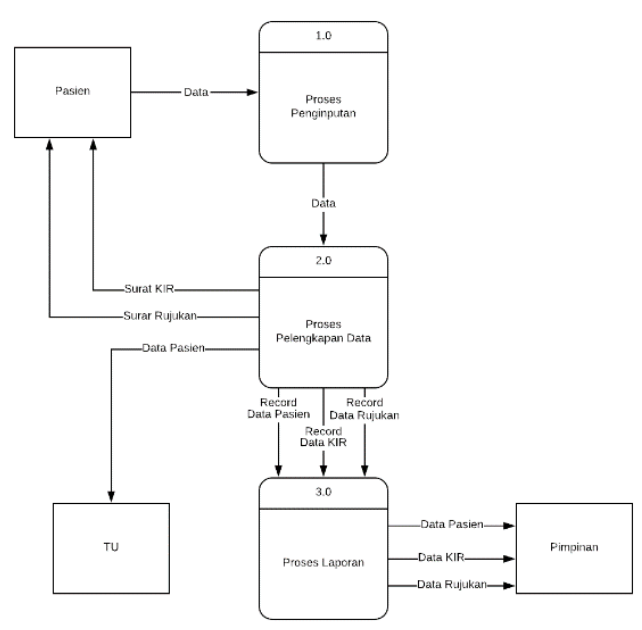

Gambar 1 Diagram Konteks

\subsection{Antar Muka Sistem}

1) Tampilan Login

Pada tampilan login ini pengguna aplikasi diwajibkan mengisi username dan password untuk bisa masuk kedalam aplikasi.

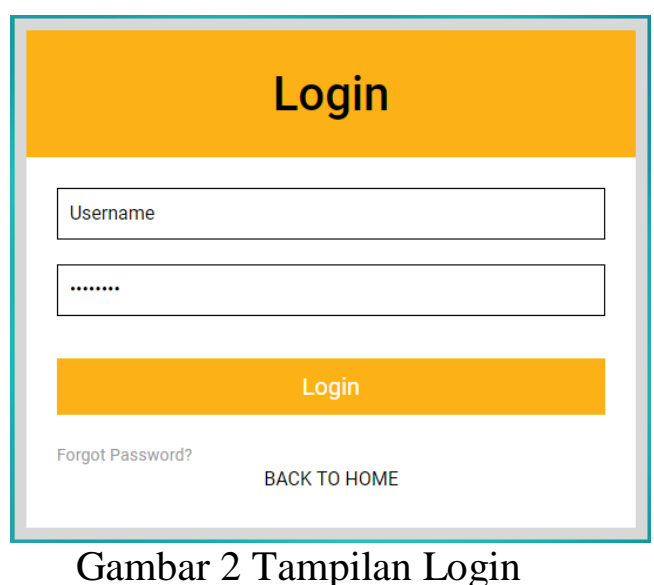

\section{2) Tambah Data Pasien}

Halaman Form input data pasien yang akan disimpan ke dalam database, setelah diisi dan klik simpan maka akan kembali ke tampilan data pasien. 


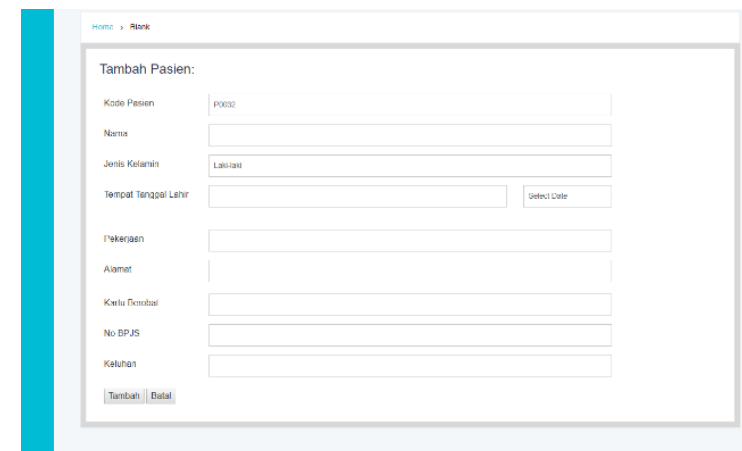

Gambar 3Tambah Data Pasien

Tabel untuk menampilkan data yang sudah tersimpan, di bagian aksi ada pilihan edit data dan hapus data dan tambah data dibagian atas pencarian data.

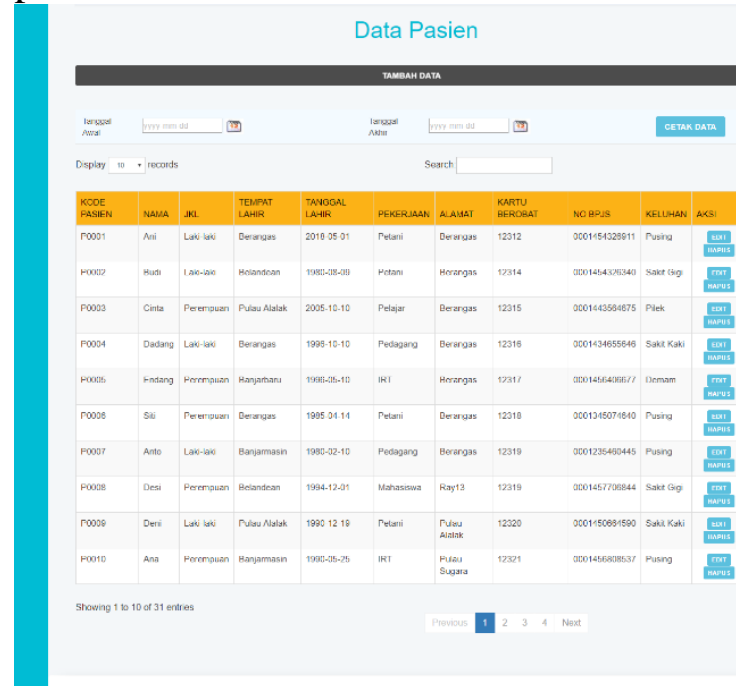

Gambar 4 Tampilan Tabel Pasien

\section{3) Tampilan Data KIR}

Halaman Form input data KIR yang akan disimpan ke dalam database, setelah diisi dan klik simpan maka akan kembali ke tampilan data KIR.
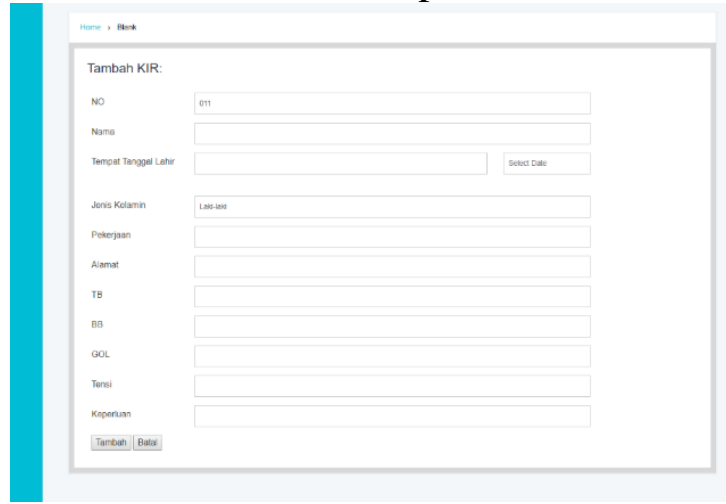

Gambar 5 Tampilan Tambah Data KIR

Tabel untuk menampilkan data yang sudah tersimpan, di bagian aksi ada pilihan edit data dan hapus data dan tambah data dibagian atas pencarian data.

Data KIR

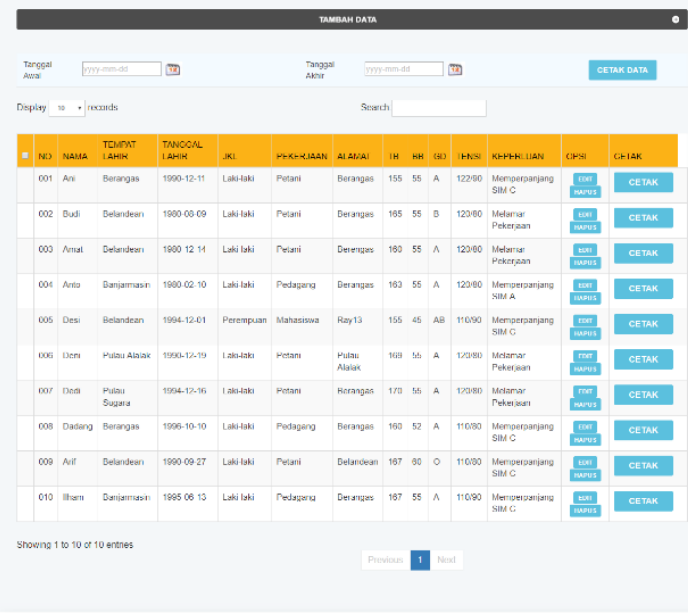

Gambar 6 Tampilan Tabel Data KIR

\section{4) Tampilan Data Rujukan}

Halaman Form input data rujukan yang akan disimpan ke dalam database, setelah diisi dan klik simpan maka akan kembali ke tampilan data rujukan.

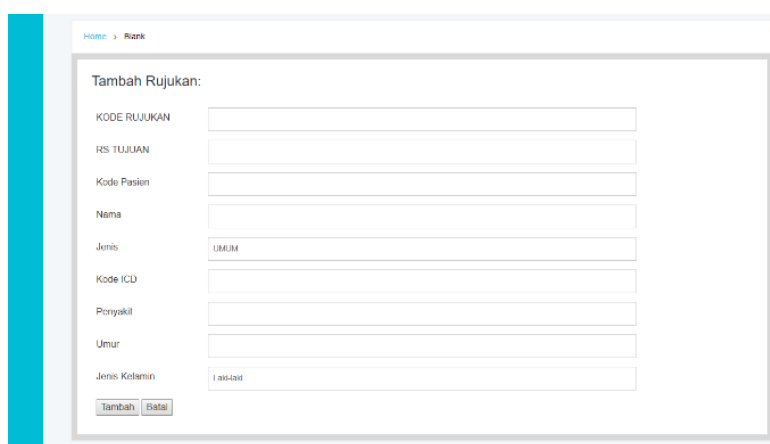

Gambar 7 Tampilan Tambah Data Rujukan

Tabel untuk menampilkan data yang sudah tersimpan, di bagian aksi ada pilihan edit data dan hapus data dan tambah data dibagian atas pencarian data. 


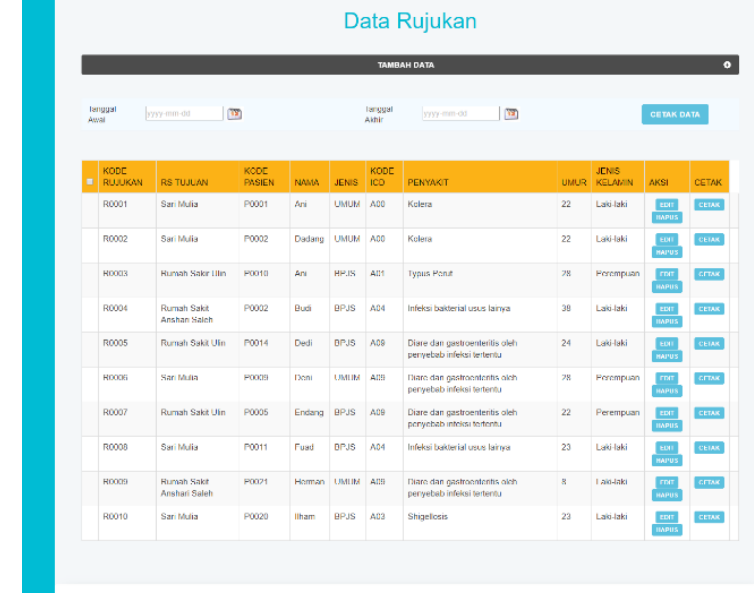

Gambar 8 Tampilan Tabel Data Rujukan

\section{5) Tampilan Data Diagnosa}

Halaman Form input data diagnosa yang akan disimpan ke dalam database, setelah diisi dan klik simpan maka akan kembali ke tampilan data diagnosa.

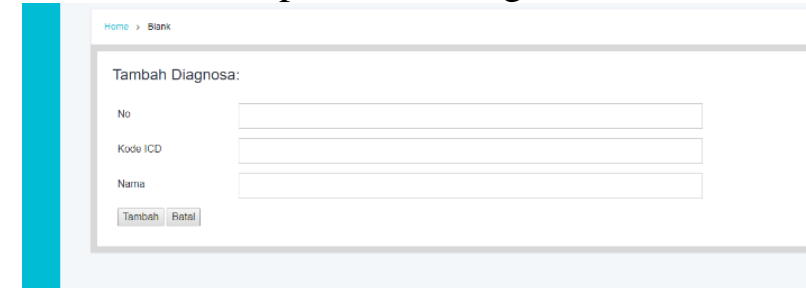

Gambar 9 Tampilan Tambah Data Diagnosa

Tabel untuk menampilkan data yang sudah tersimpan, di bagian aksi ada pilihan edit data dan hapus data dan tambah data dibagian atas pencarian data.

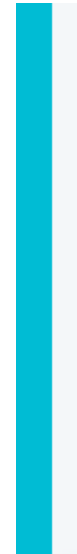

Data Diagnosa

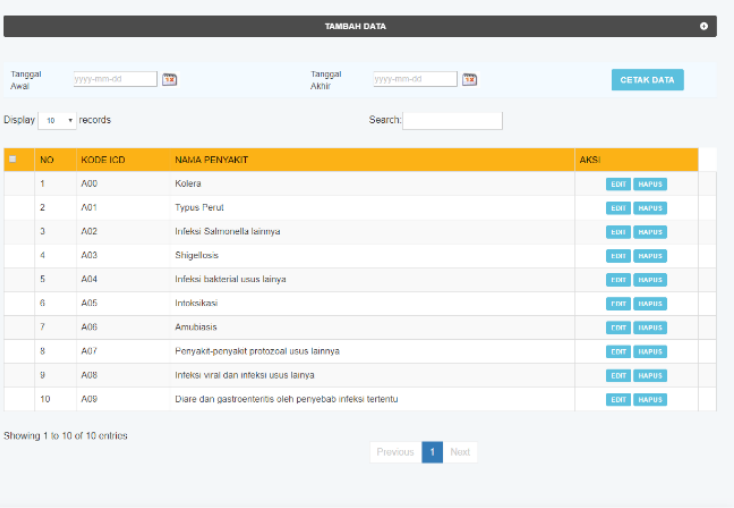

Gambar 10 Tampilan Tabel Data Diagnosa

\section{KESIMPULAN}

Setelah melakukan analisa dan pengamatan secara langsung terhadap objek penelitian, maka dapat ditarik kesimpulan sebagai berikut :

1. Aplikasi ini dibangun dengan menggunakan database MySQL dengan Bahasa pemprograman Visual Studio, yang baik tentu akan lebih efisien, karena data yang telah diolah akan tersimpan rapi dalam suatu wadah yang dinamakan database.

2. Setiap data yang dicatat atau dimasukkan dalam aplikasi akan dapat terorganisasi dengan baik, ini tentunya akan memudahkan pencarian data.

3. Penyimpanan berkas-berkas yang menyita banyak tempat pada sistem berjalan telah dapat dikurangi dengan adanya aplikasi.

4. Penyusunan dan penyajian laporan harian, bulanan bahkan tahunan menjadi lebih mudah, lebih cepat dan lebih teliti.

\section{DAFTAR PUSTAKA}

Agustinus Mujilan, S. M. (2013, Juni 1). Analisis dan Perancangan Sistem. Retrieved from https://mujilan.wordpress.com: https://mujilan.wordpress.com/201 3/06/01/analisis-dan-perancangansistem-edisi-1/

Andi. (2002). Analisis dan Perancangan Sistem. Jurnal Teknologi , 241.

Fauzan, A. S. (2012, September 17). Pengertian XAMPP \& Fungsinya. Diambil kembali dari http://caramembuatweb.net/pengert ian-xampp-fungsinya/

Haryono, R. T., Purnama,M.kom, B. E., \& S. S. (2013). Sistem Informasi Pengolahan Data Rujukan Dan Penjualan Pada Pabrik Penggergajian Batu Cv. Bumi Indah Persada.

Hedrians, D. (2012). Pengertian Literatur dan Jenis Literatur. Retrieved from http://hendriansdiamond.blogspot.c 
o.id/2012/02/pengertian-literaturdan-jenis.html?m=1

Kristianto, H. (t.thn.). Konsep Perancangan database. Yogyakarta: Andi.

Nimas. (2016, Juni 1). Pengertian Dan Contoh Data Flow Diagram (DFD) atau Diagram Alir Data (DAD). Diambil kembali dari Pro.co.id: http://www.pro.co.id/pengertiandan-contoh-data-flow-diagram-dfd/ pengertiandefinisi.com. (t.thn.). Pengertian Aplikasi dan Sejarah Perkembangan Aplikasi. Diambil kembali dari pengertiandefinisi.com:

https://pengertiandefinisi.com/peng ertian-aplikasi-dan-sejarahperkembangan-aplikasi/

Roossari, Msy.Yunia, \& Pradesan, I. (2013). Sistem Informasi Pengolahan Data Barang Pada Cv. Sinar Selabung. 